\title{
Research Article \\ Effect of Mn Content and Solution Annealing Temperature on the Corrosion Resistance of Stainless Steel Alloys
}

\author{
Ihsan-ul-Haq Toor \\ Department of Mechanical Engineering, King Fahd University of Petroleum \& Minerals (KFUPM), Dhahran 31261, Saudi Arabia \\ Correspondence should be addressed to Ihsan-ul-Haq Toor; ihsan@kfupm.edu.sa
}

Received 11 October 2013; Accepted 3 February 2014; Published 13 March 2014

Academic Editor: Theocharis C. Stamatatos

Copyright (C) 2014 Ihsan-ul-Haq Toor. This is an open access article distributed under the Creative Commons Attribution License, which permits unrestricted use, distribution, and reproduction in any medium, provided the original work is properly cited.

\begin{abstract}
The corrosion behavior of two specially designed austenitic stainless steels (SSs) having different Nickel (Ni) and Manganese (Mn) contents was investigated. Prior to electrochemical tests, SS alloys were solution-annealed at two different temperatures, that is, at $1030^{\circ} \mathrm{C}$ for $2 \mathrm{~h}$ and $1050^{\circ} \mathrm{C}$ for $0.5 \mathrm{~h}$. Potentiodynamic polarization (PD) tests were carried out in chloride and acidic chloride, whereas linear polarization resistance (LPR) and electrochemical impedance spectroscopy (EIS) was performed in $0.5 \mathrm{M} \mathrm{NaCl}$ solution at room temperature. SEM/EDS investigations were carried out to study the microstructure and types of inclusions present in these alloys. Experimental results suggested that the alloy with highest Ni content and annealed at $1050^{\circ} \mathrm{C} / 0.5 \mathrm{hr}$ has the highest corrosion resistance.
\end{abstract}

\section{Introduction}

Austenitic SSs (300 series) have been extensively used as structural alloys in various industrial applications because of their excellent corrosion resistance and good mechanical properties. However, due to the rapid increase in $\mathrm{Ni}$ cost over the last five years, there have been attempts to develop cheap stainless steels while still maintaining their relatively high corrosion resistance. Development of high Mn austenitic SSs by replacing high cost $\mathrm{Ni}$ with low cost $\mathrm{Mn}$ has gained a lot of significance during past decade or so. In these high Mn SSs, $6 \sim 11 \mathrm{wt} . \% \mathrm{Mn}(\gamma$-stabilizer $)$ is added which is 7 to 8 times cheaper than $\mathrm{Ni}$ at an equivalent weight $[1,2]$. However, it has been reported that $\mathrm{Mn}$ additions have a negative effect on the corrosion resistance properties of the newly designed high Mn SSs due to formation of MnS inclusions which enhances pitting corrosion [3-5].

Kemp et al. [6] have previously studied the effect of Mn on mechanical behavior and corrosion resistance of SSs. Their results showed that with an increase in Mn content ultimate tensile strength was improved and corrosion rate was increased; however, the pitting potential $\left(E_{\text {pit }}\right)$ was decreased with increasing $\mathrm{Mn}$ content in $0.025 \mathrm{M} \mathrm{NaCl}$ solution. So to compensate this negative effect of $\mathrm{Mn}$, nitrogen is added together with $\mathrm{Mn}$, which not only stabilizes the austenite phase but at the same time improves the localized corrosion resistance of these high Mn SSs. Nitrogen's solubility in such steels is dependent on Mn content and increases with an increase in Mn content of the alloys.

Together with other properties, corrosion resistance of high Mn can also be improved to some extent by selecting a suitable solution annealing procedure, particularly annealing temperature and time. Sands and Keady [7] found that austenitic SSs (Fe-Cr-Mn-Ni-N) have corrosion resistance similar to those of AISI 300 series SSs during atmospheric exposure and under oxidizing conditions. However, Lula and Renshaw [8] suggested that Fe-Cr-Mn and Fe-Cr-Mn$\mathrm{N}$ SSs are inferior to 300 series with respect to general corrosion resistance especially under reducing conditions. Though chromium (Cr) and Ni have beneficial effects on the corrosion resistance of SSs, $\mathrm{Mn}$ is generally considered to have a detrimental effect on the general corrosion resistance of SSs [9], so, in high $\mathrm{Mn}$ and low Ni SSs, this problem becomes serious. These results suggest that the effect of $\mathrm{Mn}$ on the pitting corrosion resistance of high Mn SSs is rather controversial with various effects being observed. According to Lunarska et al. [10], Mn containing alloys are extremely sensitive to the presence of minor constituents such as $\mathrm{C}, \mathrm{N}, \mathrm{S}$, and $\mathrm{P}$ and due to this sensitivity different controversial effects of manganese on the pitting corrosion resistance are reported 
TABLE 1: Details of chemical composition and solution annealing conditions for four stainless steel alloys.

\begin{tabular}{lccccccc}
\hline \#Alloys & Fe (wt.\%) & Cr (wt.\%) & C (wt.\%) & Ni (wt.\%) & Mn (wt.\%) & Si (wt.\%) & $\begin{array}{c}\text { Annealing temperature }\left({ }^{\circ} \mathrm{C}\right) / \text { time } \\
(\mathrm{h})\end{array}$ \\
\hline 1Ni-5Mn & 74.31 & 18.22 & 0.43 & 0.98 & 5.37 & 0.69 & $\begin{array}{c}1050 /(0.5 \mathrm{~h}) \\
1030 /(2 \mathrm{~h}) \\
1050 /(0.5 \mathrm{~h}) \\
1030 /(2 \mathrm{~h})\end{array}$ \\
\hline
\end{tabular}

$[11,12]$. Hsaio and Dulis [13] reported that nitrogen along with manganese improves the strength and toughness of stainless steels.

Solution annealing at high temperature (above $1000^{\circ} \mathrm{C}$ ) can adjust the redistribution of the element and normalizes the microstructure by dissolving nonmetallic inclusion, hence increasing the pitting corrosion resistance in SSs [14]. Tan et al. [14] in their study investigated the pitting corrosion resistance of commercial super duplex SSs annealed at seven different temperatures ranging from $1030^{\circ} \mathrm{C}$ to $1200^{\circ} \mathrm{C}$ for $2 \mathrm{~h}$. Increasing annealing temperature from $1030^{\circ} \mathrm{C}$ to $1080^{\circ} \mathrm{C}$ elevated the critical pitting temperature, whereas continuing to increase the annealing temperature to $1200^{\circ} \mathrm{C}$ decreased the critical pitting temperature. Generally annealing temperatures are kept low, around $1010^{\circ} \mathrm{C}$ to achieve fine grains and time is often kept short to avoid grain growth and scale formation on the surface. Cvijović and Radenković [15] studied the effect of corrosion resistance in $0.5 \mathrm{NaCl}$ of duplex SSs annealed in the range of $900^{\circ} \mathrm{C}-1200^{\circ} \mathrm{C}$. They achieved a maximum improvement of corrosion stability at an annealing temperature of $1200^{\circ} \mathrm{C}$. Hasannejad et al. [16] studied the effect of pitting corrosion on coated austenitic stainless steels. They heat-treated samples at $300^{\circ} \mathrm{C}, 400^{\circ} \mathrm{C}$, and $500^{\circ} \mathrm{C}$ for $30 \mathrm{~min}$ and obtained the best corrosion resistance when the heat treatment was applied on films at $300^{\circ} \mathrm{C}$. Hamada et al. [17] reported the effect of annealing on submicron grained austenitic stainless steel in acidic- $\mathrm{NaCl}$ solution $(1 \mathrm{M} \mathrm{NaCl}$ $+0.1 \mathrm{M} \mathrm{HCl}$ ). Increasing the cold rolling from $20 \%$ to $75 \%$, $I_{\text {corr }}$ was also increased significantly, but, after full annealing at $1050^{\circ} \mathrm{C}$ for $100 \mathrm{~s}$, their sample was spontaneously passivated giving lower $I_{\text {corr }}$ and $E_{\text {pit }}$.

Though there have been few studies on the role of Mn on corrosion resistance properties of SSs, the combined effect of solution annealing (temperature and time) and Mn content of the alloys was rarely reported in the literature. So in this study, specific composition alloys were developed to investigate the combined effect of annealing temperature/time as well as $\mathrm{Ni}$ and $\mathrm{Mn}$ content on the corrosion properties of four different SSs. Traditional corrosion investigation techniques such as potentiodynamic polarization (PD), linear polarization resistance technique (LPR), and electrochemical impedance spectroscopy (EIS) were employed for the experiments.

\section{Experimental Procedures}

The alloys used in this study (Table 1) were prepared by vacuum arc melting and later hot-rolled in $5 \mathrm{~mm}$ thick plates. The hot rolled plates were cold-rolled (35\%), solutionannealed at two different temperatures/time (Table 1), and cut to specimens. The specimens were polished up to $1 \mu \mathrm{m}$ with diamond paste to observe the surface morphology by SEM/EDS. For electrochemical measurement, the specimens were ground to 2000 grit emery paper and then ultrasonically cleaned with distilled water. Prior to electrochemical tests, the specimens were cathodically cleaned for $5 \mathrm{~min}$ at $-0.8 \mathrm{~V}_{\mathrm{SCE}}$ to remove any air formed oxide film. A three-electrode cell composed of a specimen as a working electrode, a Pt counter electrode, and a saturated calomel reference electrode was used for the tests.

Polarization tests were carried out at a scan rate of $0.5 \mathrm{mV} / \mathrm{s}$ in $0.5 \mathrm{M} \mathrm{NaCl}$ and $0.1 \mathrm{M} \mathrm{NaCl}+0.1 \mathrm{M} \mathrm{H}_{2} \mathrm{SO}_{4}$ nitrogen deaerated solution. Two different solutions were selected to compare the aggressive nature of sulphate and chloride ions on stainless steels with that of only $\mathrm{Cl}^{-}$ions [18]. Specimens with exposed surface area of $0.22 \mathrm{~cm}^{2}$ were used as a working electrode during corrosion experiments using PCI4/750 Gamry potentiostat. Experiments were repeated thrice to ensure the reproducibility of the data. DC105 corrosion software was used to analyze the Tafel region in order to derive important corrosion parameters. Linear polarization tests were carried out in $0.5 \mathrm{M} \mathrm{NaCl}$ solution, at $\pm 20 \mathrm{mV}$ from corrosion potential $E_{\text {corr }}$. Electrochemical impedance spectroscopy (EIS) measurements were carried out at OCP, by applying sinusoidal perturbation of $10 \mathrm{mV}$ with frequency sweep from $100 \mathrm{kHz}$ to $0.01 \mathrm{~Hz}$. The impedance data were analyzed and fitted to appropriate equivalent electrical circuit using Gamry potentiostat.

\section{Results and Discussion}

3.1. Potentiodynamic Polarization Tests in Chloride Solution. Figure 1 shows the PD curves of four SS alloys in $0.5 \mathrm{M}$ $\mathrm{NaCl}$ solution at room temperature. A general trend can be seen that as $\mathrm{Ni}$ content was increased together with the solution annealing temperature, that is, $1050^{\circ} \mathrm{C} / 0.5 \mathrm{~h}$, corrosion rate was decreased, which was measured in terms of pitting potential $\left(E_{\mathrm{pit}}\right)$ and passive current density $\left(i_{\mathrm{p}}\right)$, respectively. Corrosion current $\left(I_{\text {corr }}\right)$ and corrosion rate were calculated using Tafel extrapolation technique and data is presented in Table 2 . In $0.5 \mathrm{M} \mathrm{NaCl}$ solution, $1 \mathrm{Ni}$ $5 \mathrm{Mn}\left(1050^{\circ} \mathrm{C} / 0.5 \mathrm{~h}\right)$ sample exhibited higher pitting potential, lower passive current density, and more stable passive film as compared to the $1 \mathrm{Ni}-5 \mathrm{Mn}$ sample annealed at $1030^{\circ} \mathrm{C} / 2 \mathrm{~h}$. For the former one, pitting potential was found to be $285 \mathrm{mV}_{\mathrm{SCE}}$ as compared to $100 \mathrm{mV}_{\mathrm{SCE}}$ for the later alloy $\left(E_{\text {pit }}\right.$ for later measured at $1 \mathrm{~mA}$ current). However, the passive current density for $1 \mathrm{Ni}-5 \mathrm{Mn}$ sample annealed at $1030^{\circ} \mathrm{C} / 2 \mathrm{~h}$ was very high as compared to the former one. To confirm it further, 
TABLE 2: Electrochemical corrosion data obtained when experiments were performed in $0.5 \mathrm{M} \mathrm{NaCl}$ solution at room temperature, $25^{\circ} \mathrm{C}$.

\begin{tabular}{lccccc}
\hline \#Alloy & $\begin{array}{c}\text { Corrosion potential } \\
E_{\text {corr }} / \mathrm{mV}_{\text {SCE }}\end{array}$ & $\begin{array}{c}\text { Corrosion current } \\
I_{\text {corr }} / \mathrm{A}\end{array}$ & $\begin{array}{c}\text { Pitting potential } \\
E_{\mathrm{pit}} / \mathrm{mV}_{\text {SCE }}\end{array}$ & $\begin{array}{c}\text { Passivation current } \\
i_{\mathrm{p}} / \mathrm{A}\end{array}$ & $\begin{array}{c}\text { Corrosion rate } \\
\mathrm{CR} / \mathrm{mpy}\end{array}$ \\
\hline 1Ni-5Mn $(1030 / 2 \mathrm{~h})$ & -343.0 & $81.8 E-9$ & 100 & $10 E-6$ & $186.9 E-3$ \\
$1 \mathrm{Ni}-5 \mathrm{Mn}(1050 / 0.5 \mathrm{~h})$ & -307.0 & $45.8 E-9$ & 285.9 & $101.4 E-9$ & $167.6 E-3$ \\
$4 \mathrm{Ni}-1 \mathrm{Mn}(1030 / 2 \mathrm{~h})$ & -258.3 & $18.6 E-9$ & 260.0 & $28.64 E-9$ & $42.52 E-3$ \\
$4 \mathrm{Ni}-1 \mathrm{Mn}(1050 / 0.5 \mathrm{~h})$ & -239.0 & $4.8 E-9$ & 291.8 & $9.12 E-9$ & $17.61 E-3$ \\
\hline
\end{tabular}

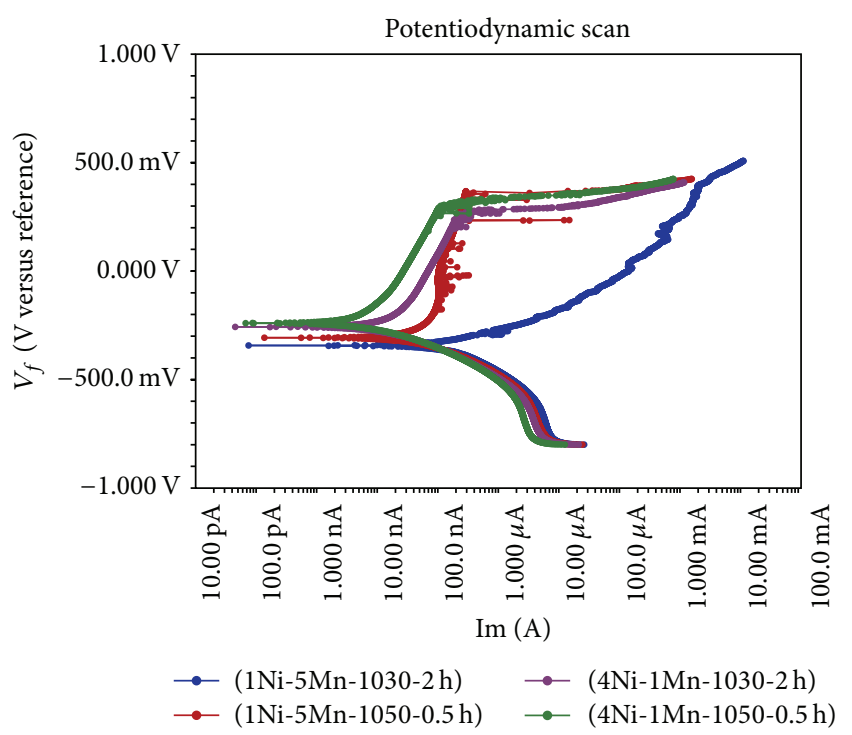

FIGURE 1: Potentiodynamic polarization response of the alloys in deaerated $0.5 \mathrm{M} \mathrm{NaCl}$ solution at $25^{\circ} \mathrm{C}$ and at a scan rate of $0.5 \mathrm{mV} / \mathrm{s}$.

values of corrosion rate for the two samples were calculated using Tafel analysis. Corrosion rate was found to be $0.167 \mathrm{mpy}$ for $1 \mathrm{Ni}-5 \mathrm{Mn}\left(1050^{\circ} \mathrm{C} / 30\right.$ minutes) sample as compared to $1.82 \mathrm{mpy}$ for $1 \mathrm{Ni}-5 \mathrm{Mn}\left(1050^{\circ} \mathrm{C} / 120\right.$ minutes $)$ sample as shown in Table 2. On the other hand, when Ni content was increased to $4 \mathrm{wt} . \%$ ( $4 \mathrm{Ni}-1 \mathrm{Mn}$ alloys), overall corrosion resistance was improved as compared to $1 \mathrm{Ni}-5 \mathrm{Mn}$ alloy (Figure 1). However, in terms of the effect of solution annealing temperature on corrosion properties, a similar trend to that of $1 \mathrm{Ni}-5 \mathrm{Mn}$ alloy was observed; that is, an increase in solution annealing temperature increased the corrosion resistance properties of $4 \mathrm{Ni}-1 \mathrm{Mn}$ alloys as well.

Corrosion potential $\left(E_{\text {corr }}\right)$ of high Mn containing alloys was less as compared to low Mn alloys because the $E_{\text {corr }}$ of SSs is closely related with $\mathrm{Ni}$ and $\mathrm{Mn}$ content of the alloys. $\mathrm{Mn}$ is an active element, so it will decrease the $E_{\text {corr }}$ of alloys, while $\mathrm{Ni}$ is a noble element and hence will increase the corrosion potential, as shown in Figure 1.

These results suggest that an increase in Mn content of the alloys is not good for the corrosion resistance properties of the SSs. Similar conclusions have been drawn previously by different researchers, such that Toor et al. [19] investigated the stress corrosion cracking (SCC) resistance of high Mn$\mathrm{N}$ alloys in terms of their repassivation kinetics and found that an increase in Mn content of the alloys decreased their
SCC resistance. They found that Mn in these alloys decreased the repassivation rate and that ultimately led to a decreased SCC resistance. It is believed that harmful effect of $\mathrm{Mn}$ on pitting corrosion resistance is related with increased number and size of inclusions which are found to be $\mathrm{Mn}, \mathrm{Cr}$, and Fe oxides and sulphides [12, 20]. Some researchers reported that Mn decreased the protectiveness ability SSs passive films due to formation of nanosized Mn oxide precipitates in the film [21]. So not only Mn oxide inclusions but also such Mn oxide precipitates in the passive film decrease the resistance to pitting corrosion.

Figure 2 showed that the number and size of inclusions were increased with an increase in Mn content of the alloys and they were mainly $\mathrm{Mn}, \mathrm{Cr}$, and $\mathrm{Fe}$. As the annealing temperature was increased $\left(1050^{\circ} \mathrm{C} / 0.5 \mathrm{~h}\right)$, number and size of inclusions were decreased. These kinds of inclusions will be the initiation sites for stable pitting corrosion of $\mathrm{Mn}$ containing stainless steel alloys. This was the reason that best corrosion resistance properties were achieved when the alloys were solution-annealed at $1050^{\circ} \mathrm{C} / 0.5 \mathrm{~h}$ (both for $4 \mathrm{Ni}-1 \mathrm{Mn}$ and $1 \mathrm{Ni}-4 \mathrm{Mn})$. It means this is the temperature as stated earlier, at which most of the harmful inclusions/impurities were dissolved and structure of the alloy becomes uniform as is clear from Figure 2.

\subsection{Potentiodynamic Polarization Tests in Acidic Chloride} Solution. It is well established that pitting corrosion of SSs is caused by film breakdown owing to chloride ion $\left(\mathrm{Cl}^{-}\right)$attack on the film. This broken site is soon transformed into a stable pit via competitive process of metal dissolution/repassivation under the conditions of critical chloride concentration and $\mathrm{pH}$ inside of the pit. In other words, it can be said that growth rate of stable pit will also depend on metal dissolution rate inside a pit in an acidified chloride solution. So in this study we have investigated the polarization response of these alloys in acidic chloride solution, that is, $0.1 \mathrm{M} \mathrm{NaCl}+0.1 \mathrm{M} \mathrm{H}_{2} \mathrm{SO}_{4}$. The decrease in $\mathrm{pH}$ causes a more rapid dissolution of the austenitic SSs and electrons released are readily consumed by cathodic reactions on the passive film away from the pit site and hence a new pit is formed, and again electron from this pit assists in cathodic reaction at some other sites. These successive attacks at various pit sites lead to autocatalytic situation enhancing the growth of the pits [20] in such solutions.

Figure 3 shows the potentiodynamic polarization response in acidic chloride $\left(0.1 \mathrm{M} \mathrm{NaCl}+0.1 \mathrm{M} \mathrm{H}_{2} \mathrm{SO}_{4}\right)$ solution at room temperature. Though the overall corrosion rate was increased as compared to $0.5 \mathrm{M} \mathrm{NaCl}$ solution 

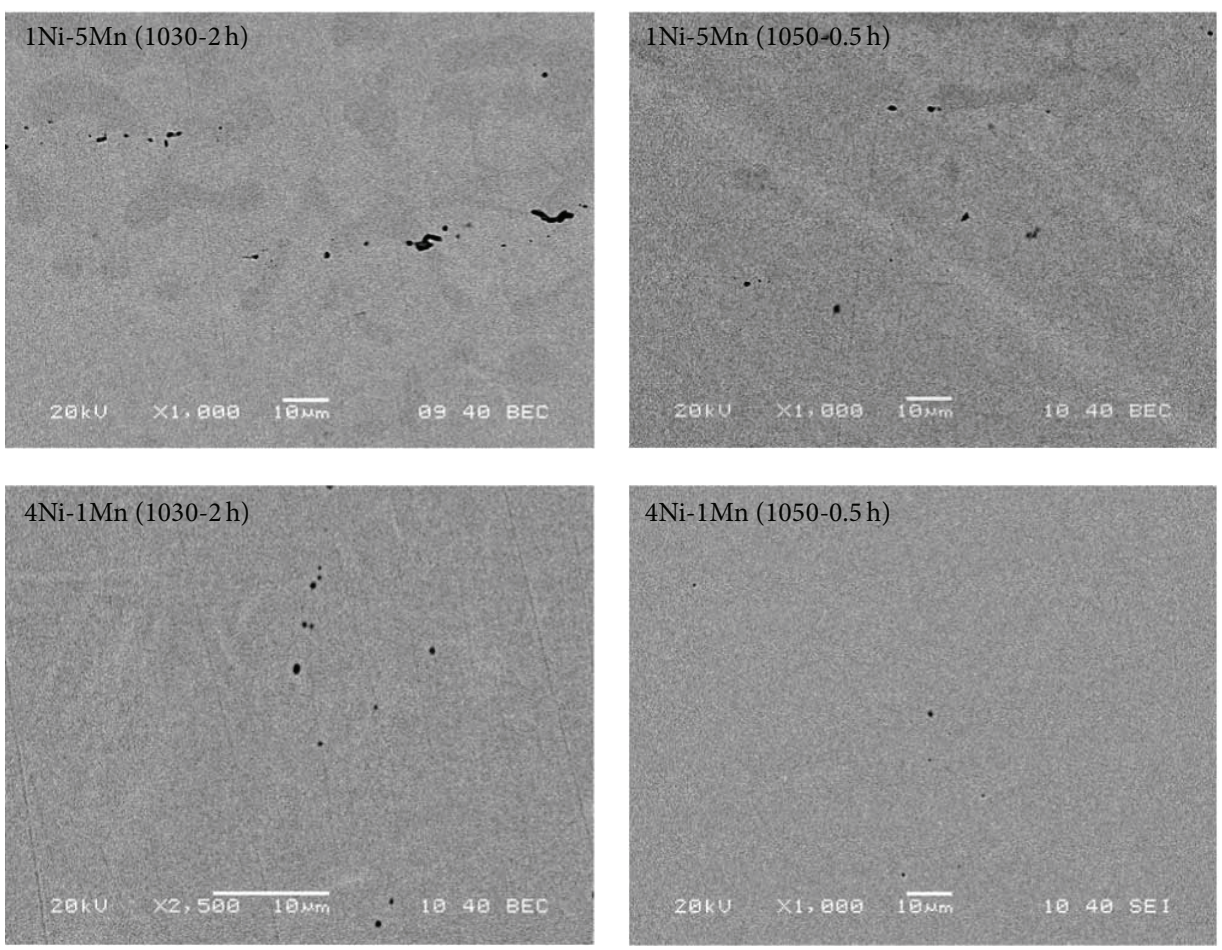

\begin{tabular}{|c|c|c|c|c|c|c|}
\hline Number of alloys & Fe (wt.\%) & Cr (wt.\%) & Mn (wt.\%) & O (wt.\%) & C (wt.\%) & Remaining \\
\hline 1 Ni-5Mn (1030-2 hr) & 55.16 & 10.97 & 20.38 & 8.9 & 4.5 & Al, Si, and Ni \\
\hline $4 \mathrm{Ni}-1 \mathrm{Mn}(1050-0.5 \mathrm{hr})$ & 64.8 & 16.2 & 6.8 & 4.1 & 2.5 & $\mathrm{Al}$, Si, and Ni \\
\hline
\end{tabular}

FIGURE 2: SEM/EDS micrographs of the four stainless steel alloys after solution annealing at different temperatures.

(Table 2) for all alloys, the trend was similar as was obtained before in the case of chloride solution; that is, those alloys which have high $\mathrm{Ni}$ content and solution-annealed at $1050^{\circ} \mathrm{C}$ have exhibited higher corrosion resistance (Table 3). As expected, corrosion rate was found to be the least for $4 \mathrm{Ni}-1 \mathrm{Mn}$ (annealed at $1050^{\circ} \mathrm{C} / 0.5 \mathrm{~h}$ ) and was the highest for $1 \mathrm{Ni}-5 \mathrm{Mn}$ (annealed at $1030^{\circ} \mathrm{C} / 2 \mathrm{~h}$ ). Critical anodic current density $\left(i_{\text {crit }}\right)$, which is an important criterion to measure the passivating ability of SSs, was increased with an increase in Mn content of the alloys.

Also it was found that the alloys solution-annealed at $1050^{\circ} \mathrm{C}$ showed higher pitting potential as compared to those annealed at $1030^{\circ} \mathrm{C}$ and these results are consistent with those obtained in chloride solution; that is, at higher temperatures more nonmetallic inclusions are dissolved in the matrix along with other secondary phases [22] and in turn increasing the pitting corrosion resistance of the alloy.

These results clearly demonstrate that an increase in $\mathrm{Mn}$ content of the alloys increases the dissolution rate of the alloys in the acidic chloride solution. Also it can be concluded from Figures 1 and 2 and from Tables 2 and 3 that solution annealing at $1050^{\circ} \mathrm{C}$ in both types of alloys (with high $\mathrm{Mn}$ or

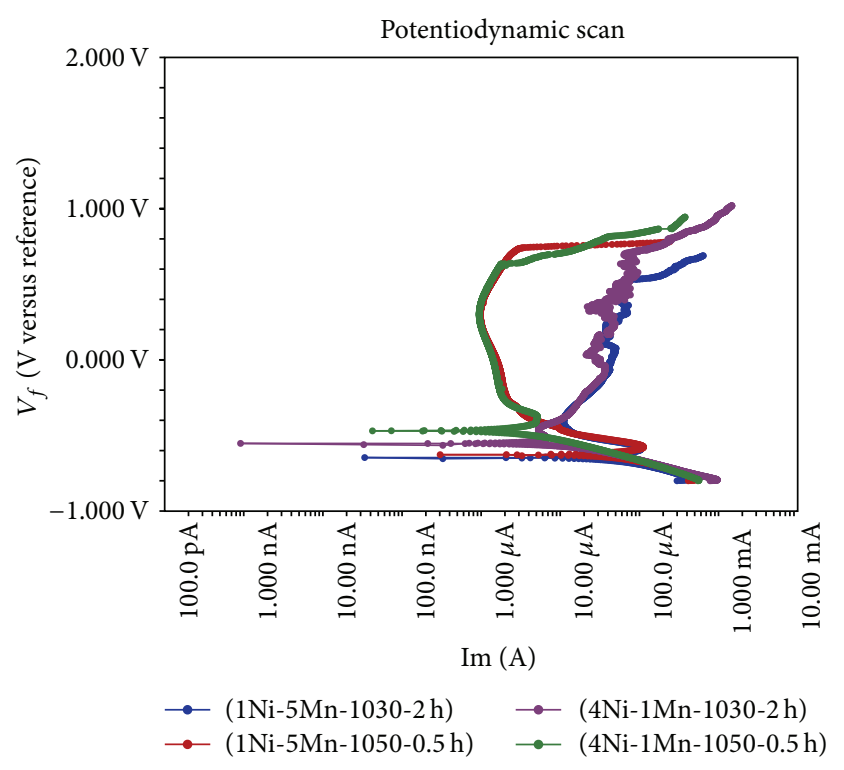

FIGURE 3: Potentiodynamic polarization response of the alloys in deaerated $0.1 \mathrm{M} \mathrm{NaCl}+0.1 \mathrm{M} \mathrm{H}_{2} \mathrm{SO}_{4}$ solution at $25^{\circ} \mathrm{C}$ and at a scan rate of $0.5 \mathrm{mV} / \mathrm{s}$. 
TABLE 3: Electrochemical corrosion data obtained when experiments were performed in $0.1 \mathrm{M} \mathrm{NaCl}+0.1 \mathrm{M} \mathrm{H}_{2} \mathrm{SO} 4$ solution at room temperature, $25^{\circ} \mathrm{C}$.

\begin{tabular}{lccccc}
\hline \#Alloy & $\begin{array}{c}\text { Corrosion potential } \\
E_{\text {corr }} / \mathrm{mV}_{\mathrm{SCE}}\end{array}$ & $\begin{array}{c}\text { Corrosion current } \\
I_{\text {corr }} / \mathrm{A}\end{array}$ & $\begin{array}{c}\text { Pitting potential } \\
E_{\text {pit }} / \mathrm{mV}_{\mathrm{SCE}}\end{array}$ & $\begin{array}{c}\text { Critical anodic } \\
\text { current } \\
i_{\text {crit }} / \mathrm{A}\end{array}$ & $\begin{array}{c}\text { Corrosion rate } \\
\mathrm{CR} / \mathrm{mpy}\end{array}$ \\
\hline 1Ni-5Mn $(1030 / 2 \mathrm{~h})$ & -645.0 & $6.9 E-6$ & 515.3 & $105.4 E-6$ & 14.50 \\
$1 \mathrm{Ni}-5 \mathrm{Mn}(1050 / 0.5 \mathrm{~h})$ & -627.4 & $6.0 E-6$ & 680.9 & $100.3 E-6$ & 13.71 \\
$4 \mathrm{Ni}-1 \mathrm{Mn}(1030 / 2 \mathrm{~h})$ & -562.2 & $3.3 E-6$ & 682.1 & $6.74 E-6$ & 6.60 \\
$4 \mathrm{Ni}-1 \mathrm{Mn}(1050 / 0.5 \mathrm{~h})$ & -470.0 & $1.0 E-6$ & 681.2 & $5.06 E-6$ & 2.40 \\
\hline
\end{tabular}

TABLE 4: Corrosion data obtained by linear polarization resistance experiment in $0.5 \mathrm{M} \mathrm{NaCl}$ solution at room temperature, $25^{\circ} \mathrm{C}$.

\begin{tabular}{lccc}
\hline \#Alloy & $\begin{array}{c}\text { Corrosion current } \\
I_{\text {corr }} / \mathrm{A}\end{array}$ & $\begin{array}{c}\text { Polarization resistance } \\
R_{\mathrm{p}} / \mathrm{K} \Omega\end{array}$ & $\begin{array}{c}\text { Corrosion rate } \\
\mathrm{CR} / \mathrm{mpy}\end{array}$ \\
\hline 1Ni-5Mn $(1030 / 2 \mathrm{~h})$ & $4.117 E-8$ & 632.8 & $94.06 E-3$ \\
$1 \mathrm{Ni}-5 \mathrm{Mn}(1050 / 0.5 \mathrm{~h})$ & $3.770 E-8$ & 691.1 & $86.12 E-3$ \\
$4 \mathrm{Ni}-1 \mathrm{Mn}(1030 / 2 \mathrm{~h})$ & $5.012 E-8$ & 712.8 & $83.51 E-3$ \\
$4 \mathrm{Ni}-1 \mathrm{Mn}(1050 / 0.5 \mathrm{~h})$ & $2.474 E-8$ & 1053.0 & $56.53 E-3$ \\
\hline
\end{tabular}

with high $\mathrm{Ni}$ ) helped in improving the corrosion resistance properties.

In order to confirm these results further, linear polarization resistance (LPR) technique was used to calculate the corrosion rate as well as polarization resistance of the alloys. LPR is a useful technique to obtain instantaneous reaction rates at the electrode/solution interface in order to effectively determine corrosion rates with a single experiment [23].Values of polarization resistance $R_{\mathrm{p}}$, corrosion current $I_{\text {corr }}$, and corrosion rate are calculated from LPR test conducted in $0.5 \mathrm{M} \mathrm{NaCl}$ solution at room temperature and results are given in Table 4 . Corrosion rates show similar trend to those obtained by PD tests in chloride and acidic chloride solutions. $4 \mathrm{Ni}-1 \mathrm{Mn}$ samples annealed at $1050^{\circ} \mathrm{C}$ exhibited higher corrosion resistance measured in terms of polarization resistance as compared to the rest of the alloys. Polarization resistance of $1053.0 \mathrm{~K} \Omega$ was observed for $4 \mathrm{Ni}$ $1 \mathrm{Mn}\left(1050^{\circ} \mathrm{C} / 0.5 \mathrm{~h}\right)$ sample, giving highest corrosion resistance with corrosion rate of $0.056 \mathrm{mpy}$. Conversely, $1 \mathrm{Ni}-5 \mathrm{Mn}$ sample $\left(1030^{\circ} \mathrm{C} / 2 \mathrm{~h}\right)$ exhibited lowest resistance of $632.8 \mathrm{~K} \Omega$ and highest corrosion rate of $0.094 \mathrm{mpy}$. These results are in agreement with what have been discussed previously in the case of polarization curves.

3.3. Electrochemical Impedance Spectroscopy. Furthermore, electrochemical impedance spectroscopy (EIS) measurements are carried out at open circuit potential (OCP), by applying a sinusoidal potential perturbation of $10 \mathrm{mV}$ with frequency sweep from $100 \mathrm{kHz}$ to $0.01 \mathrm{~Hz}$ in $0.5 \mathrm{M} \mathrm{NaCl}$ solution and results are presented in Figure 4. The EIS spectra measured at OCP were composed of high-frequency capacitive arc. It has been reported by different researchers [24-28] that the capacitive arc is considered to be closely associated with metal dissolution reaction. The diameter of the capacitive arc is related with charge transfer resistance (Rct) parameter at metal solution interface.

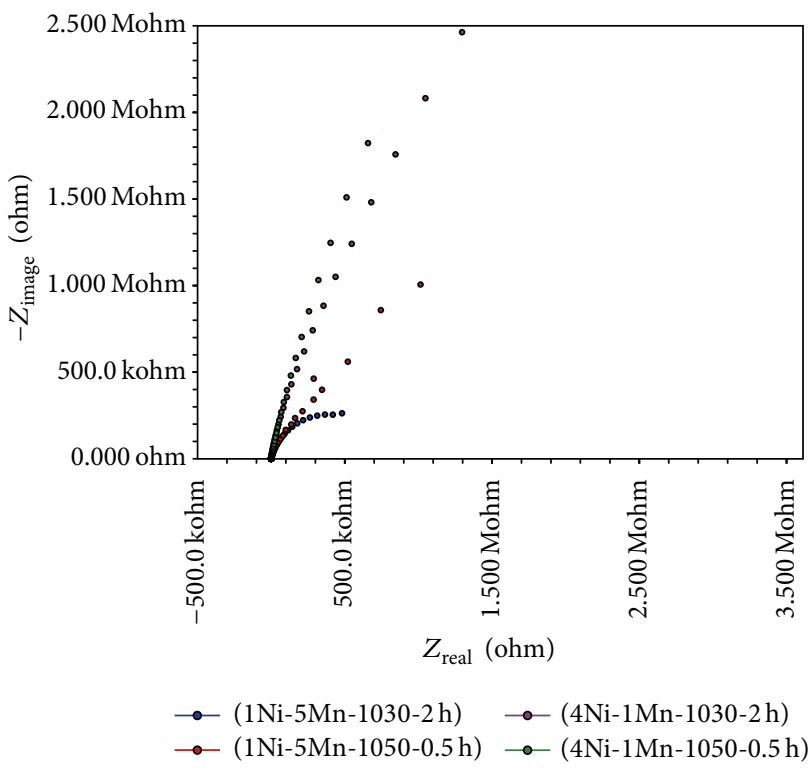

FIGURE 4: Electrochemical impedance response of the alloys in deaerated $0.5 \mathrm{M} \mathrm{NaCl}$ solution at room temperature, $25^{\circ} \mathrm{C}$.

Figure 4 shows that as Mn content of the alloys was increased, the diameter of capacitive arc was reduced significantly, which means that the metal dissolution at the metal/solution interface is influenced and increased by the addition of $\mathrm{Mn}$. Another important result was that alloys annealed at $1050^{\circ} \mathrm{C}$ exhibited bigger capacitive arc as compared to the ones annealed at $1030^{\circ} \mathrm{C}$. We have seen in Figures 1 and 3 that Mn increased the anodic current density of high Mn alloys, and that increase is associated with the fact that $\mathrm{Mn}$ addition decreased the charge transfer resistance at the metal/solution interface. Therefore the polarization resistance $\left(R_{\mathrm{p}}\right)$ value of high $\mathrm{Mn}$ alloys was the lowest 
among all specimens. Results presented in Figure 4 showed similar trend as observed in previous experiments of PD and LPR; that is, increase in Mn content of the alloys decreased the corrosion resistance of the alloys and alloys solutionannealed at $1050^{\circ} \mathrm{C} / 0.5 \mathrm{~h}$ better corrosion resistance than those solution-annealed at $1030^{\circ} \mathrm{C} / 2 \mathrm{~h}$.

\section{Discussion}

As stated earlier, the corrosion resistance of austenitic SSs depends on factors such as composition, microstructure, and annealing temperature and in this paper the effect of composition (change in $\mathrm{Mn}$ content of the alloys) as well as of annealing temperature is discussed. It is very well-established phenomenon that increasing the annealing temperature dissolves the harmful inclusions/carbides and so forth, homogenizes the microstructure, and so increases the corrosion resistance of SSs. Several researchers have studied the effect of annealing treatment on corrosion behavior of duplex stainless steels $[14,15,23]$. They have observed a significant improvement in corrosion resistance of the alloys upon increasing the annealing temperature to a certain extent. However, it was also stated that too much increase in annealing temperature, mostly $1200^{\circ} \mathrm{C}$, decreased the critical pitting potential. Afolabi and Peleowo [22] studied the effect of tempering temperature on samples austenitized at $1050^{\circ} \mathrm{C}$ for $10 \mathrm{~min}$ in oxalic acid solution. This annealing temperature was found to be very helpful in improving the corrosion resistance properties by dissolving the secondary phases and carbides which have precipitated at the grain boundaries.

Tan et al. [29] investigated the effect of annealing temperature on the corrosion resistance properties of duplex stainless steel alloy. During the welding process, ferrite/austenite phase balance is disturbed in the heat affected zone (HAZ) and it also promotes the deleterious intermediate phases. So in order to get rid of these phases and control the phase balance ratio, postweld heat treatment (PWHT) is always performed on the welded joints. It has been well observed by different researchers that there exists a strong correlation between postweld heat treatment temperature and corrosion resistance properties. Tan et al. showed that as the annealing temperature was increased, critical pitting temperature (CPT) of the alloys was increased and highest $\mathrm{CPT}$ value was found to be $33^{\circ} \mathrm{C}$, obtained at $1080^{\circ} \mathrm{C}$. All heat treated specimens showed better corrosion resistance than the as-welded specimens. They found that $\mathrm{Cr}$, Mo were found enriched in ferrite and $\mathrm{Ni}$ was enriched in austenite, which indicated that $\mathrm{Cr}$ and Mo diffused from austenite phase to ferrite phase while Ni diffused to austenite phase during the PWHT process. As a result, the pitting resistance of ferrite phases in HAZ and FZ improved and the corresponding pitting resistance of austenite phase decreased. This and similar other studies showed the importance of selecting proper heat treatment temperature to improve the corrosion resistance as well as other mechanical properties.

Regarding the composition issue, there are not many studies showing the effect of different elements such as $\mathrm{Ni}, \mathrm{Si}, \mathrm{N}, \mathrm{Mn}$ etc. on the corrosion behavior of austenitic
SSs. Pardo et al. [25] studied the effect of Mn and Mo on pitting corrosion of austenitic stainless steels and reported a considerable decrease in corrosion resistance as the $\mathrm{Mn}$ content was increased; conversely Mo had a positive effect in increasing the corrosion resistance by stabilizing the passive film. Kemp et al. [6] found that, with the addition of Mn, mechanical properties of the alloys were increased; however, corrosion resistance was degraded significantly. Decrease in corrosion resistance with increase in $\mathrm{Mn}$ content of the alloys is mainly associated with the presence of nonmetallic inclusions (NMIs) such as oxides and sulphides of $\mathrm{Mn}$ in these SSs which act as potential sites for the initiation of metastable or stable pitting. These NMIs act as pit initiation sites as was investigated by Park and Kwon [30] by examining the surface morphologies of metastable pits. They found that metastable pits occurred at the edge of these NMIs. And usually an increase in Mn content of the alloys also increases the density of NMIs, and this increased density of NMIs will decrease the corrosion resistance of SSs.

Similarly, consistent with the published literature, a significant increase in corrosion resistance (in terms of $E_{\mathrm{pit}}, i_{\mathrm{p}}, R$, corrosion rate, etc.) properties was observed with the increase in annealing temperature and $\mathrm{Ni}$ content using three different experiments such as PD, LPR, and EIS, respectively, in this study. An increase in $\mathrm{Mn}$ content of the alloys decreased the corrosion resistance of the SSs. However, on the other hand, an increase in corrosion resistance was observed when solution annealing temperature was increased from $1030^{\circ} \mathrm{C}$ to $1050^{\circ} \mathrm{C}$ for both sets of samples ( $4 \mathrm{Ni}-1 \mathrm{Mn}$ and $1 \mathrm{Ni}-5 \mathrm{Mn}$ ) in chloride and acidic chloride solutions. A high solution annealing temperature is good as it helps dissolving the nonmetallic inclusions, so the number and size of inclusions were decreased and corrosion resistance was increased.

\section{Conclusions}

Potentiodynamic, linear polarization resistance, and electrochemical impedance spectroscopy tests revealed the following.

(1) Increase in Mn content of the alloys decreased the overall corrosion rate of the $1 \mathrm{Ni}-4 \mathrm{Mn}$ alloys as compared to $4 \mathrm{Ni}-1 \mathrm{Mn}$ alloys both in chloride and acidic chloride solutions at room temperature. Increase in $\mathrm{Mn}$ content of the alloys increased the number and size of inclusions.

(2) As the annealing temperature was increased to $1050^{\circ} \mathrm{C} / 30$ minutes, corrosion rate was decreased as compared to annealing temperature of $1030^{\circ} \mathrm{C} / 120$ minutes. The reason for this improved corrosion resistance is the dissolution of harmful inclusions at $1050^{\circ} \mathrm{C}$. Also the annealing at this temperature homogenized the microstructure, which contributed in improved corrosion resistance as well.

(3) Austenitic SSs containing 4\% Ni and $1 \%$ Mn were spontaneously passivated in $0.1 \mathrm{M} \mathrm{NaCl}+0.1 \mathrm{M}$ $\mathrm{H}_{2} \mathrm{SO}_{4}$ solution compared to samples containing $1 \%$ $\mathrm{Ni}$ and $5 \% \mathrm{Mn}$. This is indicating stable passive film 
(high critical anodic current density) in low $\mathrm{Mn}$ austenitic stainless steels.

(4) Polarization resistance measured by EIS as well as by LPR method showed that low Mn alloys solutionannealed at $1050^{\circ} \mathrm{C} / 30$ minutes have a stable higher corrosion resistance.

\section{Conflict of Interests}

The author declares that there is no conflict of interests regarding the publication of this paper.

\section{Acknowledgment}

The author gratefully acknowledges the support provided by King Fahd University of Petroleum \& Minerals (KFUPM), Saudi Arabia, under the research Grant no. IN121033 for conducting this research.

\section{References}

[1] F. H. Stott, G. C. Wood, and J. Stringer, "The influence of alloying elements on the development and maintenance of protective scales," Oxidation of Metals, vol. 44, no. 1-2, pp. 113145, 1995.

[2] S. N. Basu and G. J. Yurck, "Effect of alloy grain size and silicon content on the oxidation of austenitic $\mathrm{Fe}-\mathrm{Cr}-\mathrm{Ni}-\mathrm{Mn}$-Si alloys in pure $\mathrm{O}_{2}$," Oxidation of Metal, no. 281, p. 315, 1991.

[3] H. Y. Ha, C. J. Park, and H. S. Kwon, "Effects of nonmetallic inclusions on the initiation of pitting corrosion in $11 \% \mathrm{Cr}$ ferritic stainless steel examined by micro-droplet cell," Corrosion Science, vol. 49, no. 3, pp. 1266-1275, 2007.

[4] E. G. Webb, T. Suter, and R. C. Alkire, "Microelectrochemical measurements of the dissolution of single $\mathrm{MnS}$ inclusions, and the prediction of the critical conditions for pit initiation on stainless steel," Journal of the Electrochemical Society, vol. 148, no. 5, pp. B186-B195, 2001.

[5] E. G. Webb and R. C. Alkire, "Pit initiation at single sulfide inclusions in stainless steel: I. Electrochemical microcell measurements," Journal of the Electrochemical Society, vol. 149, no. 6, pp. B272-B279, 2002.

[6] M. Kemp, A. van Bennekom, and F. P. A. Robinson, "Evaluation of the corrosion and mechanical properties of a range of experimental CrMn stainless steels," Materials Science and Engineering A, vol. 199, no. 2, pp. 183-194, 1995.

[7] G. A. Sands and M. B. Keady, "How the 200-series compares with 18-8 stainless steels," Materials Design and Engineering, vol. 47, 1958 .

[8] R. A. Lula and W. G. Renshaw, "Corrosion resistance and mechanical properties of Cr Ni-Mn stainless steels," Metal Progress, vol. 69, 1965.

[9] J. S. Stanko and D. Wellbeloved, "Manganese in corrosion resistant steel," Report, SAMANCOR Limited, Johannesburg, South Africa, 1991.

[10] E. Lunarska, Z. Szklarska-Smialowska, and M. Janik-Czachor, "Susceptibility of Cr-Ni-Mn stainless steels to pitting in chloride solutions," Corrosion, vol. 31, no. 7, pp. 231-234, 1975.

[11] J. Stewart and D. Williams, "The initiation of pitting corrosion on austenitic stainless steel: on the role and importance of sulphide inclusions ," Corrosion Science, vol. 33, no. 3, pp. 457463, 1992.

[12] J. O. Park, S. Matsch, and H. Böhni, "Effects of temperature and chloride concentration on pit initiation and early pit growth of stainless steel," Journal of the Electrochemical Society, vol. 149, no. 2, pp. B34-B39, 2002.

[13] C. M. Hsaio and E. J. Dulis, "Effect of interstitial C and N and precipitation reactions on the properties of austenitic Cr-MnC-N steels," Transactions of the American Society for Metals, vol. 52, p. 855, 1960.

[14] H. Tan, Y. Jiang, B. Deng, T. Sun, J. Xu, and J. Li, "Effect of annealing temperature on the pitting corrosion resistance of super duplex stainless steel UNS S32750," Materials Characterization, vol. 60, no. 9, pp. 1049-1054, 2009.

[15] Z. Cvijović and G. Radenković, "Microstructure and pitting corrosion resistance of annealed duplex stainless steel," Corrosion Science, vol. 48, no. 12, pp. 3887-3906, 2006.

[16] H. Hasannejad, T. Shahrabi, A. S. Rouhaghdam, and M. Aliofkhazraei, "Effect of temperature on pitting corrosion resistance of 316 stainless steel coated by cerium oxide film in $3.5 \% \mathrm{NaCl}$ solution," Journal of Materials Science and Technology, vol. 24, no. 5, pp. 715-717, 2008.

[17] A. S. Hamada, L. P. Karjalainen, and M. C. Somani, "Electrochemical corrosion behaviour of a novel submicron-grained austenitic stainless steel in an acidic $\mathrm{NaCl}$ solution," Materials Science and Engineering A, vol. 431, no. 1-2, pp. 211-217, 2006.

[18] R. T. Loto, C. A. Loto, A. P. I. Popoola, and M. Ranyaoa, "Pyrimidine derivatives as environmentally-friendly corrosion inhibitors: a review," International Journal of Physical Sciences, vol. 7, no. 19, pp. 2697-2705, 2012.

[19] I. Toor, K. J. Park, and H. Kwon, "Manganese effects on repassivation kinetics and SCC susceptibility of high Mn-N austenitic stainless steel alloys," Journal of the Electrochemical Society, vol. 154, no. 9, pp. C494-C499, 2007.

[20] J. Stewart and D. Williams, "The initiation of pitting corrosion on austenitic stainless steel: on the role and importance of sulphide inclusions," Corrosion Science, vol. 33, no. 3, pp. 457474, 1992.

[21] H. S. Kwon and K. J. Park, "Effects of manganese on the passivity of Fe-18Cr-xMn (x = 0, 6, 12)," ECS Transactions, vol. 1, no. 4, pp. 313-320, 2006.

[22] A. Afolabi and N. Peleowo, "Effect of heat treatment on corrosion behaviour of austenitic stainless steel in mild acid medium," in Proceedings of the International Conference on Chemical, Ecology and Environmental Sciences (ICCEES '2011), Pattaya, Thailand, December 2011.

[23] M. Keddam, O. R. Mattos, and H. Takenouti, "Mechanism of anodic dissolution of iron-chromium alloys investigated by electrode impedances-I. Experimental results and reaction model," Electrochimica Acta, vol. 31, no. 9, pp. 1147-1158, 1986.

[24] R. F. A. Jargelius-Pettersson and B. G. Pound, "Examination of the role of molybdenum in passivation of stainless steels using ac impedance spectroscopy," Journal of the Electrochemical Society, vol. 145, no. 5, pp. 1462-1469, 1998.

[25] A. Pardo, M. C. Merino, A. E. Coy, F. Viejo, R. Arrabal, and E. Matykina, "Effect of Mo and Mn additions on the corrosion behaviour of AISI 304 and 316 stainless steels in $\mathrm{H}_{2} \mathrm{SO}_{4}$," Corrosion Science, vol. 50, no. 3, pp. 780-794, 2008.

[26] M. Keddam, H. Takenouti, and D. Thierry, "Exfoliation corrosion of aluminium alloys examined by electrode impedance," Electrochimica Acta, vol. 42, no. 1, pp. 87-97, 1997. 
[27] G. E. Badea, A. Caraban, M. Sebesan, S. Dzitac, P. Cret, and A. Setel, "polarisation measurements used for corrosion rates determination," Journal of Sustainable Energy, vol. 1, no. 1, 2010.

[28] L. Zhang, W. Zhang, Y. Jiang, B. Deng, D. Sun, and J. Li, "Influence of annealing treatment on the corrosion resistance of lean duplex stainless steel 2101," Electrochimica Acta, vol. 54, no. 23, pp. 5387-5392, 2009.

[29] H. Tan, Z. Wang, Y. Jiang et al., "Annealing temperature effect on the pitting corrosion resistance of plasma arc welded joints of duplex stainless steel UNS S32304 in $1.0 \mathrm{M} \mathrm{NaCl}$," Corrosion Science, vol. 53, no. 6, pp. 2191-2200, 2011.

[30] K. J. Park and H. S. Kwon, "Effects of Mn on the localized corrosion behavior of Fe-18Cr alloys," Electrochimica Acta, vol. 55, no. 9, pp. 3421-3427, 2010. 

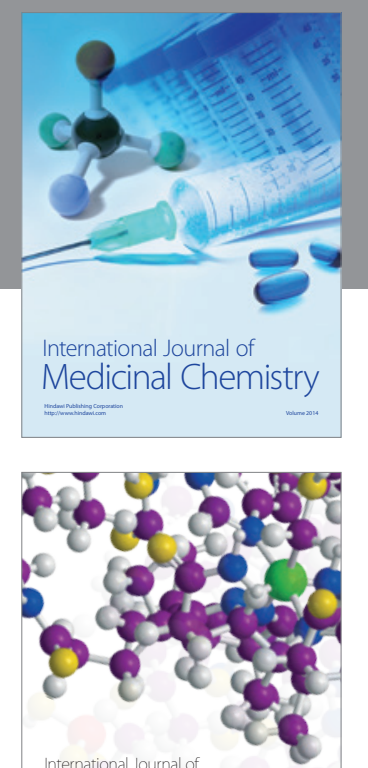

\section{Carbohydrate} Chemistry

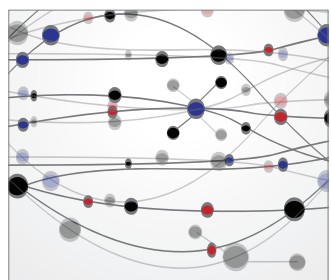

The Scientific World Journal
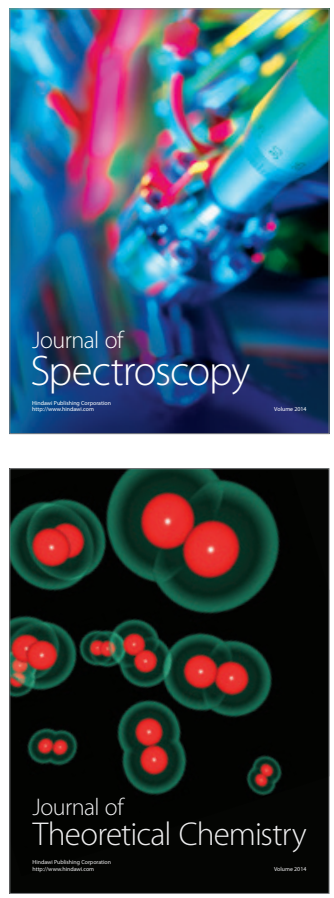
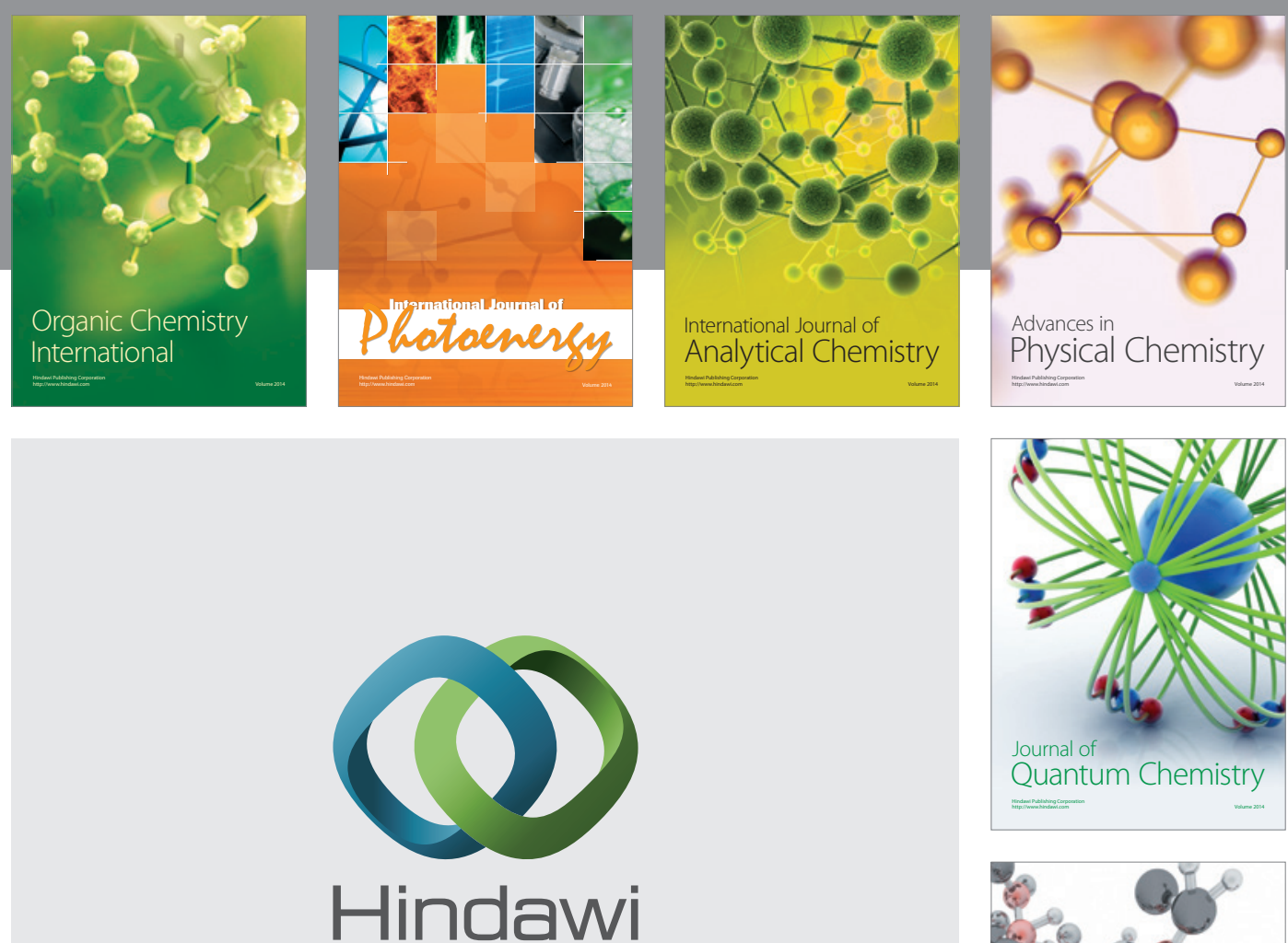

Submit your manuscripts at

http://www.hindawi.com

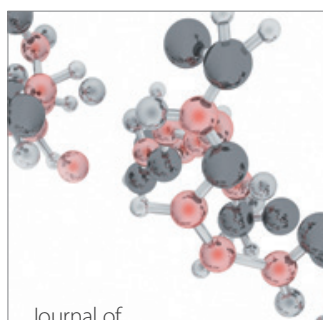

Analytical Methods

in Chemistry

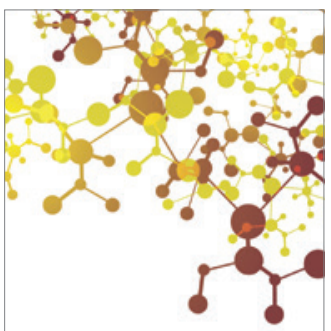

Journal of

Applied Chemistry

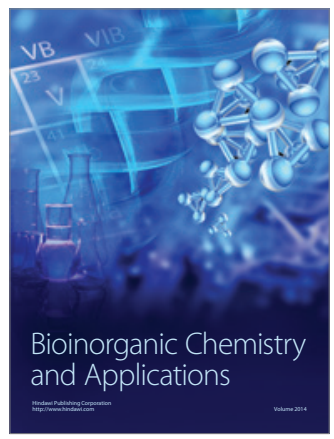

Inorganic Chemistry
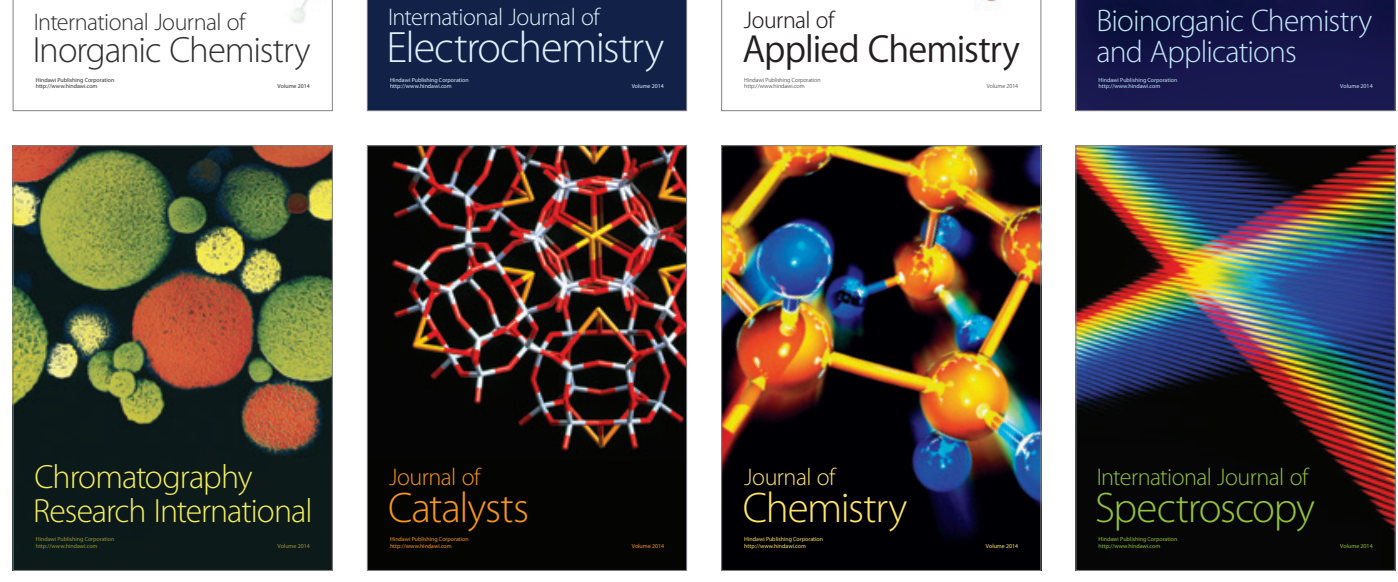